\title{
LEGAL AND ECONOMIC CONSEQUENCES OF OCCUPATIONAL ACCIDENTS AND OCCUPATIONAL DISEASES IN THE CZECH REPUBLIC
}

\author{
Miroslaw Czapka', Urszula Kontny², Violetta Kozik3 \\ 'University of Economics and Administration in Bytom, \\ ${ }^{2}$ Technical University of Opole in Opole,
}

\section{${ }^{3}$ Higher School of Economics and Administration in Bytom}

The characteristics concerning the law regulation of occupational accidents and occupational diseases and the principles governing the process of compensation as a consequence of these events in the Czech Republic are included in the article. The content of the article is divided into: introduction, occupational accidents, occupational diseases, compensation for work accidents or occupational diseases as well as a summary. It is important that the referred regulations are specific to the Czech Republic and fundamentally different from the rules adopted in this field in other countries.

Key words: occupational accident, occupational disease, compensation for accident at work or occupational disease

\section{Introduction}

Analyzing the development of protection of life and health of workers in the labor process, it can be concluded that the economic aspects have been perceived by scientists and practitioners dealing with this issue only for a few years. Some seeds of taking into account issues of economic inclusion and safety at work, can be seen in the activities of the International Labor Organization. The research team working on behalf of that organization has analyzed the national systems of protection of working conditions in terms of taking into account the economic principles of their organization and operation. Presented findings indicated clearly that the majority of the countries included in the analysis, do not attach attention to the economic aspects of protection of life and health of workers. However, in those countries in which they are taken into account, they can be described as marginal. A few years have passed since the publication of the results in question. In the meantime, both an increase in costs interest relating to both the prevention of accidents as well as the effects of occupational accidents and occupational diseases can be observed. The following article is another one, dedicated to the legal and economic consequences of occupational accidents and occupational diseases. Series of articles devoted to this subject aim to enable readers to make a comparative analysis of legislation on this issue in different countries.

\section{Accidents at work}

Accidents at work and the reporting procedure are governed by the provisions of the Council of Ministers Ordinance OJ No 494/2001. By contrast, the definition of an accident at work is contained in $\$ 190$ of the Labor Code [1]. According to it, if an employee in the performance of work tasks or in direct connection with these tasks suffered the health damage or his death as a consequence of an accident (an accident at work), then the employer, with whom the employee during the case remained in the employment relationship, is responsible for the loss suffered in this way. It should be noted that in contrast to legislation adopted in Poland, the Czech Republic do not consider as an accident at work when the event occurred to the employee on the way to or from work. Through the way to work and back - in accordance with Czech law - the way from the place of residence (accommodation) to the worker's place or any other place designated to perform work tasks and vice versa is meant, in the case of employers in the forestry, agriculture and construction it is also the way to the designated place of meeting and back. When it comes to the concept of an accident at work, it looks similar in those two countries. The definition of an accident at work in Poland and the Czech Republic is not limited to the situation that occurred in connection with the performance of work tasks or in a direct connection with them.

According to the Ordinance OJ No 108/1994 by the performance of work tasks and direct relationship with them, it is meant:

- Performing work duties arising from the attitude to work, another action performed by order of the employer and the action which is the subject of travel order,

- Operation performed for the employer on the initiative of the trade union, council employee, or agent for safety and health at work or other workers, or action performed for the employer on its own initiative, if the employee does not need to comply with a specific authorization, or if they do not perform it despite the clear employer's prohibition and voluntary assistance organized by the employer, 
- Steps needed to perform the work and activities during the current job or necessary to be performed before the commencement of work or after the normal operations and during meal breaks and rest, performed at the employer's facility. However, the way to work and back, eating a meal, health tests, or research in the health facility, or the way back and forth, are excluded from those activities unless it takes place in a facility of the employer. Research in health care facility, performed to their employer's order or research in connection with work at night, first aid study and the way to these tests and back, are the activities which remain in direct connection with the employee's duties,

- Employees trainings organized by the employer or trade union organization or superior authority, aim at skills raising.

In addition, an accident at work shall be treated as an accident that the employee suffered in connection with their duties performance. It is important that, in accordance with $\$ 261$ of the Labor Code, claims of the employee (does not apply here, therefore, a threeyear limitation period) in the provision of exercise for damage to their earnings because of an accident at work or occupational disease $(\$ 194$ and $\S 195$ of the Labor Code) or other body injury ( $\$ 187$ of the Labor Code) and claims for people who are dependent on the person who suffered death in the accident $(\$ 199$ of the Labor Code), are not subjected to expiration. However, the rights of the individual benefits are barred. For this reason, the employer must take special care to document an accident at work and lead in this regard a clear and comprehensive records [2].

The basic obligations of the employer with the emergence of an accident at work and preventing occupational diseases include:

- Examine the causes and background to the accident involving the employee, unless his health allows that, and with the participation of the competent authority or representative of a union for the safety and health at work (health and safety the outside specialist) and no change of the accident site conditions without a serious reason;

- Preparing and keeping records of all occupational accidents, which resulted in the worker injury leading to disability in excess of three calendar days, or the death of the worker;

- Transferring an injured worker a copy of the event minutes, in the case of fatal accident, to members of his family;

- Keeping records of all accidents in the workplace, including those that were not the cause of incapacity for work or were a result of their inability to work not exceeding three calendar days;

- Notification of accidents at work and the message protocol of the case referred to the authorities and institutions (as by a decree of the Council of Ministers - OJ No. 494/2001);

- Taking steps to avoid recurrence of accidents at work;

- Keeping records of employees who are considered to suffer from an occupational disease that arose at the workplace of the employer and to ensure to remove these type of conditions that cause threat of causing occupational diseases.

As in Poland, if there was a bodily injury or death to an employee in the performance of work tasks, or in a direct connection with them, (referred to as «an accident at work»), his employer is responsible for the loss suffered as a result of, by whom the worker was employed at the time of the accident.

On the basis of the Council of Ministers Orders OJ No 494/2001, the employer must keep a register of accidents in the book, in such a way as to contain all the data required to compile the minutes of the incident. Minutes of the case, the employer should complete up to 5 working days, after the notification of accidents at work, using the the model of the accident, which is attached to this ordinance.

\section{Occupational diseases}

Compensation proceedings in case of occupational diseases is carried out in a similar way as in the case of accidents at work (see $\$ 193$ of the Labor Code, or $\S$ 194 of the Labor Code) [3]. An employer, with whom the employee last worked, is responsible for damage, resulting from occupational disease. Before its statement in the employment relationship under the conditions in which the occupational disease arises, which has been affected. Specialized health centers are entitled to the recognition of occupational diseases, based on the opinion issued by the medical center, part of which is a branch or a clinic of occupational diseases or occupational medicine. Occupational health center passes a judgment on the incident, in case of which the suspicion arose that the occupational disease is concerned (hereinafter referred to as «affected») at the request of your doctor or person who is ill.

Such studies carried out by:

- Occupational health center, where a workplace is located, in which the ill person performs a job within the labour-law relationship or similar;

- The health center assessing health status of people who carry out or has carried out work in tropical conditions or in other areas with special conditions; 
- Occupational health center, which is referred as a place of residence area of the other people, who have been engaged to work in conditions which lead to occupational diseases (hereinafter referred to as relevant occupational health center).

The correct occupational health center shall assess the disease on the basis of determining the health status before the illness, the results of medical examinations, as well as examining the conditions of the disease appearance. The conditions of illness are studied by:

- Sanitary lodgings, on which area the ill person performed or performs work within the labour-law relationship or similar professional relationship;

- The doctor of the State Office for Nuclear Security in case of illness, which may have been affected by work connected with ionizing radiation or radioactive materials;

- Appropriate occupational health center, on the basis of the information about the illness creation, handing over in writing by the employer.

After disease evaluation, a relevant occupational health center, will provide a case, in order to verify the conclusions from the illness and its opinion to the center of occupational diseases in the area of which it is located. A proper center for occupational diseases, in case of inaccurate or incomplete assessment of disease, will complement the necessary documents (foundations), or will return the case to complete it by the appropriate medical work center. After verifying the conclusions from the illness, the relevant diseases center will pass an opinion, in which occupational disease is recognized. Moreover, a copy of the opinion will be sent to person who is suffering from an occupational disease and to the appropriate medical work center, or will pass an opinion stating that an occupational disease does not occur, and will send a copy of the opinion to the suffering person.

Opinion, on which an occupational disease is recognized, includes:

- Name, Social Security number, identification number of the insured person, the place of permanent residence of the person suffering from an occupational disease, a health insurance company (here: sickness, note. Transl.), where the person is insured and the employer's marking, in which the disease occurred;

- The profession identification which led to an occupational disease;

- The health capacity assessment of the person suffering from occupational disease necessary to work;

- Diagnosis of occupational disease in accordance with the international classification of diseases;
- An occupational disease marking;

- The date of occupational disease assertion, ie the day on which the examination was conducted, during which the first symptoms were later recognized as an occupational disease.

Opinion, which recognizes an occupational disease, is sent by an appropriate military occupational diseases center or occupational diseases center to:

- The State Health Institute in Prague - Center for Occupational Health and Occupational Diseases;

- A family doctor that a person suffering from an occupational disease is registered to

- A competent preventive care doctor, when it comes to an employee

- Sanitary and Epidemiological Station at the workplace, in which a person suffering from an occupational disease last pursued an activity in conditions which illnesses arise. Or the State Office for Nuclear Security doctor, who assessed the conditions for creation of disease in case of illness, which was founded in relation to work with ionizing radiation or radioactive materials;

- Health insurance company (here: the equivalent of Polish healthcare fund) in which a person suffering from an occupational disease is insured;

- The last employer, for whom a person suffering from an occupational disease was working in circumstances in which illnesses arise, in this case, some data is not included in the opinion (the diagnosis of occupational disease in accordance with the international classification of diseases).

Records of people affected by an occupational disease, are conducted by a competent occupational health center. Occupational diseases are recorded by the employer in the same way as accidents at work. Number of occupational diseases is one of the important indicators of the employer's safety level.

\section{An accident at work or occupational disease compensation}

The employer is obliged to repair the damage (pay a compensation, a certificate) even if they comply with the obligations arising from legal provisions and other regulations for ensuring the safety and health at work, unless they are not discharged from those obligations according to $\$ 191$ of the Labor Code. The employer is exempt from liability to the full extent in the case they prove that:

- Damage was caused in such a way that the injured worker himself infringed the legislation or other 
provisions aimed at ensuring the safety and health at work, or commands to ensure the safety and health at work, although he was well acquainted with them and knowledge of them and following them were required and systematically controlled, or

- Damage was caused by the injured worker because of his intoxication state or resulting from the use of other intoxicating substances, and the employer could not prevent the damage, and that those factors were the sole cause of injury.

The employer is partially exempt from liability in the case, if they prove that:

- Injured worker from his own fault breached of legislation or other provisions designed to ensure the safety and health at work, or command to ensure the safety and health at work, although he was well acquainted with them, and that the breach was one of the reasons of injury;

- One of the causes of the damage was the employee's intoxicated state or other use of narcotic substances by an employee;

- The worker has suffered injury because he acted contrary to the normal rules of behavior in such a way that it seems to be obvious that although they have not infringed the provisions aimed at ensuring the safety and health at work or commands to ensure the safety and health at work, they acted recklessly, and with a view to their qualifications and experience must have been aware that it might cause damage to their health.

If an employer is partially discharged from the responsibility of (see above), part of the damage will be determined, which the employee will cover according to the degree of culpability; However, the employer pays at least one third of the damage. An employer when assessing whether an employee violated the law or other provisions designed to ensure the safety and health at work, cannot rely only on general provisions, under which each is obliged to act in such a way that do not constitute a health risk to themeselves and others. The employee must be proved that they infringed the specific rules or instructions aimed at ensuring the safety and health at work, which the worker has become familiar with, as documented, and their knowledge has been checked (preferably in the form of the test). Compliance with these rules has been systematically required by the employer and controlled by him. For reckless behaviour cannot be considered pure carelessness and proceedings arising from the risks of work. An employer may not be released from responsibility in case if the employee suffered an accident at work when they were trying to prevent a threatening injury of their employer, or danger directly threatening the life or health, unless the employee himself caused such a situation deliberately [4].

An employee who has suffered an accident at work or in which the occupational disease was found, should be paid the equivalent (here: the compensation) by the employer, the extent to which he is responsible for damage (unless they are exempt from liability under $\$ 191$ of the Labor Code), for:

- Damage to earnings

- Pain and difficulty with functioning in a society on the basis of medical opinion (Regulation OJ No. 440/2001)

- Deliberately born costs associated with the treatment

- Material damage.

The manner and extent of compensation (benefits) the employer is obliged to agree immediately to the competent authority and the federal employee. Due to liability establishment, it is recommended to set up the so-called compensation committee, whose lineup should consist of experienced workers who have no emotions and subjective approaches will assess the incident in accordance with the law, when dealing with accidents at work. Recommended composition of the committee are: (not provided) - a lawyer, an accountant, health and safety specialist, a representative of the company's management, a representative of the trade unions. It is recommended to set up a committee with an odd number of members, provided that there will always be at least three people. A compensation for damage to earnings in the period of incapacity for work and compensation for damage to earnings after the period of incapacity to work for the same reason are separate claims, which do not happen at the same time.

A compensation for damage to earnings in the period of incapacity for work makes a difference between the average employee's earnings before the injury suffered in an accident at work or occupational disease, and the full amount of sickness benefit.

A compensation for damage to earnings is also entitled to continue in case of incapacity for work due to the same accident or occupational disease; the worker's average earnings before the emergence of another injury, is here taken into consideration. However, if the employee was entitled to compensation for damage earnings after the incapacity for work, before the emergence of another injury, they will be paid a compensation according to the preceding paragraph up to the amount payable, entitled under $\$$ 195 of the Labor Code, if a worker had been unable to work. However, the earnings after an accident at work or occupational disease, is considered as a benefit sick. 
A compensation for damage to earnings, after the incapacity to work or the recognition of the disability or partial dsability, shall be granted to an employee in such an amount that, together with his wages after an accident at work or occupational disease, adding the possible disability pension or partial disability pension, payable from the same reason, it was equal to his average income before the damage occurred. The increase in disability pension due to a permanent incapacity to work, reducing the pension under the legislation on social security or worker's earnings, which were reached by the increased working involvement (here: as a result of additional work), are not taken into cosideration.

An employee who, refuses a job which has been provided to him, without a serious reason, shall be entitled to compensation for damage to earnings within the meaning of the preceding paragraphs, only by taking into consideration the difference between the average amount of earnings before the damage occurred, as a result of an accident or occupational disease, and the average income, which would be received for the work that has been offered to them. The employer does not pay the employee a compensation for the damage, to the amount that would earn for the work, which they refused to take without serious reasons.

A compensation for damage to earnings, after the period of incapacity for work, the worker is entitled up to the end of the calendar month in which they are 65 years age.

A compensation for pain and difficulty with functioning in a society, which an employee was afflicted by an accident at work or occupational disease, shall be paid once.

Fatal accidents at work. If a worker died as a result of an accident at work or occupational disease, the employer of his liability is required to:

- to cover the costs of treatment,

- to cover the relevant costs associated with funerals,

- to cover the cost of living of people who are dependent on the deceased,

- single compensation payment to people who are dependent o the deceased,

- to cover property damage.

Claims arising from the above, are independent of, whether the injured worker has presented their claims for compensation in a specified date with. The abovementioned claims are not subjected to expiration.

The costs associated with treatment and funeral costs associated are paid to the person who bore these costs. Funeral benefit is deducted from cost of the funeral expenses, under the Act on State social assistance.

Covering the maintenance costs of the deceased is entitled to people who were dependent on the deceased or the maintenance of which he was obliged to pay. By calculating the compensation, the average earnings of the deceased is taken into account; maintenance costs of all the deceased family members, cannot exceed the total amount of the deceased 's compensation for health damage to earnings under $\$$ 195 of the Labour Code and may not be paid longer than it would be entitled to the person who died under $\S 195$ paragraph. 4 Labor Code.

A single compensation is entitled to to the spouse and eligible child. A child shall be entitled to compensation amounting to $80000 \mathrm{CZK}$ and spouse of $50000 \mathrm{CZK}$. In justified cases, a single compensation totaling CZK 50000 shall be payable to the parents of the deceased. A higher amount can be specified in a collective agreement or an internal regulation. This applies also employers who do not engage in economic activity.

A compensation for damage to property, shall be entitled to worker's heirs.

In addition to the above-mentioned consequences of occupational accidents and occupational diseases, in the Czech system of compensation, ie. damages for pain and suffering are also important. Damages for pain (painful) as a result of accidents which have occurred after 1.1.2002 r. (inclusive) shall be determined by scoring rate, as presented in Annexes 1 and 3 to the Decree of the Minister of Health OJ No $440 / 2001$, ie for the pain caused by injury to health, its treatment or disposal of its consequences. But the pain is any bodily and mental suffering caused by injury to the health of a person who has suffered such prejudice (the «victim») and scoring bodily harm is defined in a medical opinion. If scoring assessed damage to their health is not given in Annexes 1 and 3 to the Decree of the Minister of Health - OJ No $440 / 2001$, then a scoring bodily injury is used, which may be closely evaluated to compare to the injury in terms of soreness. Among others Compensation for difficulty to function in a socjety is distinguished in the legislation. A compensation for the difficulty to live in the social life is determined by the rates of scoring, which is presented in Annexes 2 and 4 of the Decree of the Minister of Health - OJ No $440 / 2001$, ie the consequences of bodily injury, which are permanent and have an adverse impact on the victim functioning in a socjety, especially in fullfilling the living and social necessities, including the implementation of present profession or preparation for the profession, continuing education and functioning in family life, political, cultural and sports events, including the victim's age at the time of creation of damage to their health (the «consequences»). A compensation for the difficulty in functioning 
in a society must be proportionate to the nature and consequences of the assumed development in the area in which the victim's capacity to function in life and society is limited. Scoring a difficulty in functioning in the social life is defined in medical opinion. If scoring of the assessed consequences was not specified in Annexes 2 and 4 of the Decree of the Minister of Health - OJ No 440/2001, then the consequences scoring will be applied, which can be closely evaluated to compare the consequences according to their nature and scope. Regulations present in details the scoring settlement to determine the amount of compensation in individual cases. In determining the scoring of pain (painful) the current phase of the pain is estimated, the doctor 's assessment is based on a detailed written information provided by the previous doctor. In determining the scoring of pain in a particular scale point, the scope and manner of creation of bodily injury, its severity, treatment history, including the complexity of the applied treatment and resulting complications are also taken into account. The pain evaluation (painful) can be done only during the stabilization of the pain. The first surgery in the case of closed fractures and injuries to bones or other body systems, is evaluated as an open wound; by performing any subsequent operation in these cases, the scoring is increased by half. The arising pain in connection with the operation did not originally assumed, which, however, the initial injury led to, is evaluated as the newly created pain. In determining the scoring difficulty in functioning in socjety, the seriousness of bodily injury, the anticipated development and course of treatment are assessed. If the victim, in connection with the earlier difficulty functioning in public life, has already been compensated and currently the subject of compensation is the aggravation of the difficulty in functioning in a society, which was not expected at an earlier compensation, the used amount of scoring that has been already made, will be deducted from scoring of a new difficulty in functioning in a society. If the functioning of the victim's social life was already difficult because of the previous health status changes, not related to the estimated health detriment, only the consequences that arose from the bodily injury are estimated, which eventually led to a significant deterioration in the health status of the previous amendments.

If the injury:

- Requires a complex treatment, scoring bodily injury shall be increased according to Annexes 1 and 3 to the Decree of the Minister of Health OJ No $440 / 2001$ of up to $50 \%$ of the total scoring, through a complicated method of treatment is meant especially wound infections, extending treatment duration,

- Requires an extremely complicated treatment, bodily injury scoring shall be increased according to Annexes 1 and 3 to the Decree of the Minister of Health - OJ No 440/2001, up to twice of the total amount of scoring, through an extremely complicated way of treatment is meant especially involving long-term treatment of pulmonary ventilation, vascular catheterization or dialysis,

- Leads to particularly serious consequences, bodily injury scoring shall be increased according to Annexes 2 and 4 of the Decree of the Minister of Health - OJ No 440/2001, maximum $50 \%$ of the total scoring; through a particularly serious consequences of bodily injury are meant those consequences, which significantly reduce or significantly alter the functioning in life, due to the age of the victim and his functioning in life [5].

While, if the injury is assessed by a larger number of items, scoring of these items shall be aggregated. If, however, regarding the damage to the same body, the sum of the scores may not exceed the scoring with their anatomical or functional loss. The amount of damages for pain (painful) and difficulty in functioning in a society are determined by the scoring presented in medical opinion, the value of 1 point is $120 \mathrm{CZK}$. In exceptional cases, deserving special consideration, the court may increase the amount of damages based on the Decree of the Minister of Health - OJ No 440/2001. Medical opinion to determine the amount of compensation in individual cases:

- is prepared by an opinon doctor, who is a victim's leading doctor; in the case of occupational disease, it is a leading doctor who is entitled to giving opinions on occupational diseases,

- is issued by a health center, whose doctor gave a medical opinion, in the case of occupational diseases, health care center authorized to give opinions on occupational disease, whose doctor prepared the opinion.

A medical opinion is given:

- In case of pain ( considered as painful), on condition that health of the injured is considered as a stable,

- In case of difficulty functioning in a society, usually only after one year after the injury. A new medical opinion can be issued in the case of a clear deterioration in succession. This opinion replaces the existing medical opinion.

The medical opinion is prepared on the basis of comprehensive written information provided by the physicians who participated in the treatment of the victim. If the victim's treatment involved more health 
centers, medical opinion is given by a health center, whose doctor gave a medical opinion; when it comes to occupational disease, a medical opinion is given by the entitled health center.

A medical opinion always includes:

- Methods, which help the doctor draw the conclusions presented in its opinion,

- Positions of the annexes of the Regulation, on basis of which the scoring was made.

- Justification for any increase in scoring above the limits presented in the Annexes to the Regulation - OJ No 440/2001.

Medical opinion containing the signature of a doctor, its personalized stamp, the health center

\section{Bibliography}

1. Spirt M., Zakonik prace, wyd. Portal, Praha 2005.

2. Jouza L., Prace, wyd. MERITUM, Praha 2005.

3. Galvas M., Pruchlova I, Pracovni pravo po vstupu stamp and the date is given to the victim on condition of a written acknowledgment of receipt.

\section{Conclutions}

Rules governing the consequences of an accident at work or occupational disease in the Czech Republic, specify in detail the various cases in which the victim should be compensated. However, it should be underlined that it is characterized by a certain specificity where the pain that accompanies the victim is taken into consideration. Such a solutions is rarely found in the regulations regarding compensation for accidents at work or occupational disease.

CR do EU, wyd. CP Books, Brno 2005.

4. Galvas M., Pracovni pravo zakon, komentare, vzory, judikatura, CP Books, Brno 2005.

5. Cermak J., Bezpecnost prace, wyd. Eurounion, Praha 2001.

\section{Miрослав Чапка', Урсула Контні², Віолета Козік³ ЮРИАИЧНІ ТА ЕКОНОМІЧНІ НАСАІАКИ ПРОФЕСІЙНИХ НЕШАСНИХ ВИПААКІВ ТА ПРОФЗАХвОРЮВАНЬ У ЧЕСЬКІЙ РЕСПУБАІШ}

'Університет економіки та управління в м. Битом,

¿Технічний Університет Ополе у м. Ополе,

зВиша школа економіки та управління в м. Битом

У статті наведена характеристика регулювання нещасних випадків та профзахворювань, а також принципів управління процесом компенсацій, як результат таких випадків у Чеській республіці. Зміст статті включає: вступ, професійні нещасні випадки, профзахворювання та резюме. Важливо зазначити, що проведені регуляторні заходи є специфічними для Чеської республіки та значно відрізняються від правил, прийнятих у інших країнах.

Ключові слова: професійні нещасні випадки, компенсація за нещасний випадок на роботі або за профзахворювання

\section{Мирослав Чапка', Урсула Контни², Виолетта Козик}

\section{ЮРИАИЧЕСКИЕ И ЭКОНОМИЧЕСКИЕ ПОСАЕАСТВИЯ ПРОФЕССИОНААЬНЫХ НЕСЧАСТНЫХ САУЧАЕВ И ПРОФЗАБОАЕВАНИЙ В ЧЕШСККОЙ РЕСПУБАИКЕ}

'Университет экономики и управления в г. Бытом,

${ }^{2}$ Технический Университет в Ополе, г. Ополе,

Высшая школа экономики и управления в г. Бытом

В статье дана характеристика юридического регулирования несчастных случаев и профессиональных заболеваний, а также принципов управления процессом компенсаций, как следствие таких происшествий в Чешской Республике. Содержание статьи включает: вступление, профессиональные несчастные случаи, профессиональные заболевания и резюме. Важно отметить, что приведенные регуляторные меры являются специфическими для Чешской Республики и фундаментально отличаются от правил, принятых в этой области в других странах.

Ключевые слова: профессиональные несчастные случаи, профессиональные заболевания, компенсация за несчастный случай на работе или за профзаболевание

Author: M. Czapka is a full Professor at Silesian College of Economy and Administration in Bytom, PL 41-902 Bytom, Poland, E-mail: rektorat@gwsp.pl

Published as submitted by the author(s). 